\title{
ОБИЧАЈИ ЖИВОТНОГ ЦИКЛУСА КОД СРБА У РУМУНИЈИ: СВАДБА У СЕЛИМА ПОЉАДИЈЕ
}

\begin{abstract}
У јулу 2019. године, тим Етнографског института САНУ обавио је теренска истраживања у селима Луговет, Златица и Соколовац (Румунија, жупанија Караш-Северин) са циљем прикупљања података о начинима празновања свадбе, крсне славе и Божића код Срба у селима Пољадије. У раду је представљен део теренске грађе о свадбеним обичајима који се везују за српску заједницу у насељима смештеним у равничарском делу југо-западног Баната. Лична, проживљена искуства склапања брака саговорници су евоцирали у наративима од којих су, због ограничености рада, три приказана у целини, а преостали делимично.
\end{abstract}

Кључне речи: обичаји, Пољадија, Румунија, свадба, Срби.

Велику захвалност дугујем мојим саговорнищима: Ђурищи Теодоровићу, Велинки Урошевић, Веселинки Николић, Рузмаринки Војиновић, Озрену Ружићу, Наталији Вукасановић, Анћелки Новичић, Милени Балоји, Адаму Љубиши и Светлани Жигум. Посебну захвалност упућујем Милу Косашу на техничкој помоћи на терену.

1.

\section{Обичаји животног циклуса: свадба}

Брак се дефинише као био-социјална заједница двеју особа различитог пола, друштвено одобрена, са више функција: репродуктивном, економском, социјалном и обредно-религијском [Златановић, 2003: 24]. Свадба је ритуал који прати склапање брака и представља најважнији, најразрађенији и садржински најбогатији ритуал животног циклуса. Никола Пантелић под свадбеним обичајима подразумевају се све припреме, радње и обреди који претходе чину венчања двоје младих људи (предсвадбени обичаји), затим само венчање, свадбено весеље и све што се дешава док оно траје (обичаји на дан свадбе) као и догађаји и обреди непосредно након свадбе (обичаји

\footnotetext{
${ }^{1}$ bojana.bogdanovic@ei.sanu.ac.rs

${ }^{2}$ Текст је резултат рада на пројекту Исираживане исиорије и куличуре Срба у Румунији, у организацији Научног центра при Савезу Срба у Румунији (Темишвар) и истраживања обављеног при Етнографском институту САНУ за чију је реализацију средства осигурало Министарство просвете, науке и технолошког развоја РС.
} 
после свадбе) [Златановић, 2003: 25]. Наведени сегменти образују ,јединствену ритуалну целину у оквиру које сваки од њих има свој назив и извесну самосталност и заокруженост“ [Златановић, 2003: 25]. У традицијској култури је склапање брака третирано превасходно као колективан чин. Пре би се могло окарактерисати као успостављање везе између две породичне заједнице него као удруживање два индивидуума [Бандић, 2004: 241].

\section{2.}

\section{Свадба у селима Луговет, Златица и Соколовац}

Истраживање свадбе код Срба у селима Пољадије (Румунија, жупанија Караш-Северин), спроведено у јулу 2019. године у оквиру пројеката Истраживање културе и историје Срба у Румунији у организацији Научног центра при Савезу Срба у Румунији (Темишвар) и Културно наслеђе и идентитет Етнографског института САНУ (МПНТ РС 177026) 3 , вршено је анализом субјективног доживљаја посматране друштвене праксе од стране припадника српске заједнице у селима Луговет (рум. Сâmpia), Златициа (рум. Zlatiţa) и Соколоваи (рум. Socol). Наведена насеља припадају такозваним пољадијским селима, а налазе се на левој обали реке Нере, у подножју планине Локве [Крстић, 2015: 5]. У локалном говору ова села називају „пољадијским“, а то ће рећи насеља смештена у равничарском делу југо-западног Баната [Крстић, 2015: 5]. У њима живе (или су до скора живели) махом Срби као већинско становништво: према попису становништва из 2011. године у Луговету живи $54,6 \%$, у Златици $34 \%$, а у Соколовцу $63,6 \%$ Срба [Степанов и Степанов, 2014: 28-30]. ${ }^{4}$ Током боравка на терену, полуструктурирани интервјуи вођени су са 10 саговорника, оба пола и старије старосне доби (од 65 до 92 године). Њихова лична, проживљена искуства склапања брака са супружницима исте (српске) етничке заједнице биће приказана кроз транскрибоване исказе од којих су, због ограничености рада, три приказана у целини, а преостали делимично. Испред сваког транскрипта наведени су просторни и временски контекст биографске приче, док су испод сваког сегмента исказа у загради дати подаци о полу и старости саговорника у тренутку бележења. На крају транскрипата нису наведена имена информатора будући да за то од већине саговорника није добијена сагласност. Такође, нису унета ни имена њихових супружника.

\footnotetext{
${ }^{3}$ Рекогносцирање терена спровео је тим Етнографског института САНУ у саставу др Милина Ивановић Баришић, др Ђорђина Трубарац Матић и др Бојана Богдановић.

${ }^{4}$ Према попису становништва из 2011. године , Срба је у укупном броју становника у Румунији, било 18.076 (0,008980\%), односно 0,54\% од свих 20 засебно регистрованих мањина [Степанов и Степанов, 2014: 16-18]. Од укупног броја Срба у Румунији, 5.036 (27,86\%) живи у жупанији Караш-Северин [Степанов и Степанов, 2014: 25] којој административно припадају села Луговет, Златица и Соколовац у којима су и обављена теренска истраживања.
} 


\section{Луговет, 1958. година}

\section{младожења - Србин из Луговета /млада - Српкиња из Луговета}

„Мој муж је био девета кућа одавде, знала сам га цео живот. Његова баба је дошла да пита за мене, а моја мајка јој рекла: „Боже сачувај, па нећемо да дамо тако младу девојку!“. А ја имала 16 година. Где ли сам пожурила? Али у то време су све моје другарице почеле да се удају, једна, друга, трећа... И ја, шта ћу, хајде и ја да се удам! На прошевину су дошли његови родитељи, брат, сестра, на коњима, много лепе коње имали. И то са музику да се зна да је прошевина. И нису, наравно, дошли празних руку: добила сам много лепе аљине, материјале, то сам ја добила. Ко је имао носио је и златно, његови нису толико имали. Ми смо их дочекали у дворишту, моја родбина. Спремили смо до супе до печења. Договрили смо кад ће свадба, где ће свадба, шта ће се спреми... Гледали су да свадба буде у недељу, пре поста. И ми смо седели ту за асталом, а договарали су родитељи. Ондак смо закитили коња пешкиром, лепо урађеним. Тај пешкир је значио да је девојка испрошена. Од прошевине је прошло пар недеља. За то време ја нисам ишла код њега, али је он прелазио до мене. И ондак смо седели у соби он, ја, моја стрина, отац, ма какви сами да останемо. Ми смо правили картице - позивнице, папирне, однели их у Темишвар на штампу, на њима кратко: „Позивамо тога и тога, на свадбу дана тог и тог, у толико и толико сати...“. То је био трошак. Велики. У суботу пред свадбу, кренули смо да позивамо госте. Имали смо једну флашу са ракијом, она је била лепо украшена и ондак: напред армоника, ондак ми, јер смо заједно звали госте, а за нама омладина. Који је дао пешкирче, који је дао марамче - то је значило да долази на свадбу. На дан сваде дошле девојке да ме спремају. Наместиле ми косу, вео, ја сам имала белу аљину, шила ми је једна шнајдерка. У дворишту се свирало, веселило. Младожењини су исто стигли са музиком, не знам баш шта су тачно радили, јер сам ја била у соби, такав је обичај био да се млада не појављује. Мене је извео брат па је са девером кренуо да се „црће“ - дај оволико, не дам толико... Када су ме предали, повело се коло. Ухватили су се и момци и девојке, и старо и младо. Повео га је момак па ја за њим. Ко је хтео од родова, пружио је новац музици. Било је мало колача, мало пића. Ондак смо сви у једној поворци кренули ка Општини, на почетку ја и младожења, кум, старојко, девер, па остали. Ја сам се само у Општини венчала. После венчања смо са све музиком и гостима обишли село, цело село изашло да види младенце. Ма то је била ларма до Бога! После тога смо отишли у Дом, једно 300 душа. Одмах почела музика. Супе, меса, сарме, печења, торте, све се то служило. Се пратио кум кући: метнуло му се шта треба: печења, торте, ракије... Пре него што сам ушла у кућу, моја ми стрина бацила јаје, живо јаје, и ја сам га протурила овако кроз аљину, каже да се „олакшаш“. То је значило да се лако породим. Свирци свирали. Ујутру су сви редом играли „пераја“, метнули јастук па око њега. Када смо кренули ка његовој кући, испратили нас са музиком. Пред кућом смо мало играли и певали. Сутрадан се у Дому још мало јело, пило, свирало...“ (ж. 77 г.) 


\section{Златица, 1966. година}

\section{младожења - Србин из Златице /млада - Српкиња из Соколовца}

„Ја сам мог Б. први пут видела на сеоској слави 27. септембра овде у Златицу и заљубила се у њега. Моји нису дали да се узмемо, само су говорили: „Не у Златицу, не у Златицу!“ Шта ја знам што. И ја кажем баби, мајкиној мајки, она ме баш волела: „Ја Б. волим, а ти ради шта се мора!“ И она смисли да ме свекар и свекрва манеду, као на силу. И они ме манеду. И ондак моји нису имали куд. Просидба је била око месец дана пре свадбе, негде у октобру. На просидбу су дошли Б., свекар и „ђеђа“ - свекрва, на коњима. Моји су спремили леп ручак. Не сећам се свега, али се сећам да сам ја само седела у соби на кревету, мајка ми је рекла ту да седим. Знала сам да ће моји да ме дају, али сам ипак мало стрепела... Договорили су да свадба буде већ 27. новембра. То су договорили родитељи, нас нису ништа ни питали. Ондак је моја мати везала на коње пешкире, имала сам их спремне, и са једне и са друге стране били су сликовани. То је био знак да је брак уговорен. Ондак сам свекрву пољубила у руку и она ме је даривала, искрено да ти кажем не сећам се шта ми је дала. Госте смо звали седам дана пред свадбу. Девојка је позивала своје, момак своје. У звање мојих гостију је ишао мој брат са говорџијама. И ондак по селу са флашом ракије - чутуром. Она је била украшена пешкиром, јер цвећа није било, био је новембра. Она није имала више од литре и имала је малу рупу да не може пуно да се нагне. И ондак из куће у кућу. Па су говорџије из сваке украли по нешто, шале ради. Ко је хтео да дође увезао би марамицу на ту чутуру. Од четвртка смо почели да спремамо храну. Тада није било као сад. Морао си судове, столове да донесиваш од комшија, родбине... Није сваки имао довољно шерпи, лонаца, чаша... На дан свадбе, мене су спремали у мојој кући. Имала сам једну мајсторицу, она ми је хаљину припремила, она ме је очешљала, нису били фризери да одеш, па ми наместила вео. Окупидули су се сви код мене, док не стигну момкови. Стигли су око 10 сати колима, тзв. тавницама. Е, када су они стигли, кренуло је да се цениду за младу. Мене је извео брат, али у то време није било као саде велики новци, него онако симболично. А купила ме је Б. сестра, јер му је брат био много мали. Она је била девер. Онда се коло извело на сокак. И док је коло играло, ја сам изнела корпу пуну дарова. Па сам даривала кума, па старојка, па куму и тако редом. То су били материјали, они за хаљине или одела. Ондак смо кренули. Млада није смела да се окрене када крене од куће, такав је био обичај. Прво у Општину, а ондак и у Цркву. После црквеног венчања ја сам поново повела коло. И ондак смо кренули код Б. У погачарима, младиним сватовима, ниси могао да пошаљеш не знам колико него се њихов број уговорио пре свадбе, да би људи знали колико да припреме хране. Када смо ушли, онај што води свадбу, жарач, приказао је дарове младине породице. Ја сам добила материјал, тепсију, лонац, ништа посебно. Ондак су ме свекар и свекрва препели на столицу да фрљам жито на четири стране, три пута сам подигла накоњче. Ондак се мало играло, па се јело, па се играло, па се јело и тако. Послужење је било: супа, ринфлаш са сосом, сарма, печење, колачи и торте. Ко је хтео да игра са младом, морао је да плати. Тај новац је ишао свекрви и стављао јој се у кицељу. Весеље је трајало целу ноћ. Кум се 
пратио са свадбе са музиком. Пратиле су га говорџије. Носио је и дар: печено прасе и ракије. Ујутру се играло „перје“ - сви се ухвате у коло који су остали. Они најближњи су остали до сутра поподне да се још провеселе...“ (ж. 71 г.)

\section{Соколовац, 1972. година}

\section{младожсеьа - Србин из Соколовца /млада-Српкиња из Толвадије}

„Ја сам своју жену Ј. упознао на послу, биле су тада фабрике, радило се. Она је Српкиња из Толвадије. Лепа. Водили мало пријатељство па се заљубили. Ондак одлучим да се женим. Пре свадбе су били „уговори“. Ту су мало интервенисале моје тетке, стрине и шта ја знам, да се види село, па да се види кућа. На „уговор“ смо ишли ја, отац, мати, тетка, стриц, кум који се не мења од дедовине и тако. Поклони су били обавезни. Увек је то морало да буде нешто добро, ниси могао било шта да понесеш. То се на време спремало. Моја мати je 5 година раније припремила за моју свадбу дарове. То је чекало спаковано у шифоњеру. Прво, морао сам прстен да покажем. Даровао сам и оца, мати, тетку, све смо то знали ко је у кућу и шта се носи. Ондак смо остали на ручку: супа, ринфлаш, сарма, печење, колачи, торта. Пили смо, била једна армоника, па се мало и певало. Ондак су кренули договори за момачко вече па за свадбу. Договорили смо дан свадбе, ми смо се венчали после два месеца. Договорили смо и ко плаћа свадбу: музику кум, њени дали руво и девојачку спрему, а ми све остало. Сватове смо звали месец дана раније, да могу да се спреме. А то смо ишли ја и J., са ракијом и јабукама, од кума па до последње куће. У четвртак пред свадбу је почело да се коље, то се све спремало, један је био за печење, један је био за сарму, па се мало попило, па се шалило и тако. У суботу преподне девер је однео Ј. хаљину коју јој је купио. Око 15 сати, стигла музика. Ондак сам ја узео чутуру, пуну ракије, па са сестрицом, говорџијама и жарачем, то су се звала „свињска браћа“, и са све музиком кренуо из куће у кућу које су звате. У кући нам давали знак хоће или неће доћи: ако вежу џепницу или мали пешкирић ондак долазе, ако не, ондак ништа. Мало се задржали, отпили ракије па даље. И тако по целом селу до увече. Ондак смо се вратили до моје куће на вечеру. То је било момачко вече. Било музике, цело село, играло се тако, али само до поноћи да би се одморили за сутра. У недељу у 10 сати музика је била спремна. Код мене се скупили моји, код Ј. њени гости. Било послужење и код једних и код других. Прво се ишло за кума: ја, говорџије и музика. Говорџије чим су изашли из дворишта почели да певају бећарци. Даровали смо кумову кућу, штофови, материјали, кошуље, није то било као сада. Па смо довели кума кући, сви се окупили, мало се послужили, мало провеселили па смо тек ондак кренули по младу. До кола, на почетку колоне били ја и девер, иза старојко, тај мора да буде из фамилију, мени је био моје матере брата син, кумови па сви остали. На зачељу говорџије, а последњи су били музиканти. Деца трчала и викала: „Изгоре ти, куме, кеса!“决 кум имао спреман одговор: „Не чујем, не чујем!“‘. И наравно да је имао паре. Вриска, писка, весело! Код младе опет било послужење, се играло коло, се веселило. Старојко и девер се „музли“ из џепа за младу. Па онда довели једну „намештаљку“, обукли неку другу као младу. Па ту било убеђивање да ли је права или није, па фешта. Младу платили ста- 
ројко и девер. А продала је нека жена, тетка која знаде да се ценкаду. Када је изашла права млада, ја је „прихватио“, одигао је па повели коло. И онда жарач, који је водио целу свадбу, мало убрзао полазак, да се не одуговлачи. Ондак смо отишли у Општину. Обавили шта треба, одиграли коло па ондак у Цркву. Тамо било исто венчање, музика спремно чекала испред, па када се завршила Црква, кренули смо око целог села, певајући сватовце: „Ал’ је лепа млада, по моди се влада, у бело се обуче, лепа је к’о луче...“ и тако даље. И свака кућа изашла и на тацни износила вина, ракије да се наздрави. Када смо то обавили, смо отишли у Дом културе. Прво смо мало играли напољу, прво коло водио кум. Па се сликавали, ондак ушли, па се послужила ракија, музика свирала, певач купио паре. Пре супе, жарач узе микрофон па објави: „Драги гости, нешто се десило, куварици је пала супа, испекла се, мора у болницу!“. Па кренуше од кума са тацном да сакупљају паре, доста се ту сакупило и ондак су паре дали нама, младенцима. Ондак дошла супа од живинског меса коју млада није јела да нам деца не би била слинава, па ринфлаш, сарма, печење, колачи и торте. Изашла музика мало и напоље, па се окупио свет, и позвани и непозвани, да виде младенце. Око поноћи поново се служила храна и музика мало одморила, па наставила. E, онда се крала млада: узели је момци у кола и сакрили је негде. Па ја, наравно, морао да платим, па је после вратили, све шале ради. Око 2 сата иза поноћи, жарач на микрофон захвалио гостима и ондак мало шале, па се даривали гости редом: кумови, старојко, тетке итд. Ми смо добили материјале, кошуље, жерсеје, мало лонаца за кућу и то. И негде око 3 ујутру, кумић дремао, онај дремао, овај дремао и видео жарач да је дошло време за „воденицу“. То се спремило унапред и брашно и све, па смо као млели ту у сали, а то су сви гледали, сви су се пробудили. То је брашно требало да се плати, па опет тацна да се стављају паре. Ко није хтео да плати, жарач узме мало оног брашна и дуне на лепе аљине, па ти види хоћеш ли да платиш! Ондак се кум пратио кући, цела свадба, све говорџије, само они најпијанији нису могли, уз песму и галаму. На крају свадбе, то је већ било јутро, свекар се метнуо у колица, венац љутих паприка му се метнуо око врата и негде где је највећа бара или камен ту га треснеду. Ондак смо дошли пред моју кућу. У дворишту стојао сточић, на њему сито са житом и кукурузом да га млада поспе по гостима и накоњче дете из ближе фамилије, али мало, јер га је одизала 3 пута. Ондак је свекрва даривала Ј., био материјал неки и нешто од злата. Ондак смо играли „пераја“ и то је био крај. У понедељак се поново окупило народа јер је остало пуно хране, дао се музики још који динар и то је то.“ (м. 70 г.)

Приказани наративи показују да формирање брачне заједнице између супружника исте (српске) етничке заједнице чине следеће сукцесивне фазе груписане у три веће целине: предсвадбени обичаји (,прошевина“ / „просидба“" , уугвор“ и позивање сватова), обичаји на дан свадбе (окупљање сватова, одлазак по кума, одлазак по младу, преузимање младе, венчање, долазак сватова у Дом културе, свечани обед, свадбено весеље, испраћај кума и повратак сватова у младожењин дом) и обичаји после свадбе (окупљање сватова у мла- 
дожењином дому). У складу са прецизно дефинисаном структуром свадбених ритуала који прате склапање брака између супружника исте (српске) етничке заједнице, основни елементи прославе (време, простор, организатори, учесници, активности и предмети који се том приликом користе 5 ) су релативно стабилни параметри у посматраним просторним контекстима: свадба се у сва три села организује недељом и то пре или после (божићног или ускршњег) nоста (време); младожењина кућа, младина кућа, Црква, Општина и Дом културе представљају просторне пунктове у којима се реализују сукцесивне фазе свадбене церемоније (простор); према казивању испитаника организатори свадбе су породице младенаца (организатори), док свадбени ритуали акцентирају: младенце, кума, старог свата, девера, говорџије, жарача и свекрву (учесници). Локалне специфичности свадбених обичаја у три просторна контекста посебно долазе до изражаја у активностима и предметима који се том приликом користе: примера ради, у посматраним селима веома је богато сећање на симболичне радње које су биле пожељне да млада обави када дође у нови дом: „Пре него што сам ушла у кућу, моја ми стрина бацила јаје, живо јаје, и ја сам га протурила овако кроз аљину, каже да се „олакшаш“. То је значило да се лако породим.“ (Луговет, ж. 77 г.) / „Ондак су ме свекар и свекрва увели у собу гди су седели кум и старојко. Они су ми бацили два леба које сам ставила испод мишке и ондак су ме они нешто питали, а ја сам требала да им одговорим: „Добро вече, куме и старојко, светло ви видело!“ (Златица, ж. 71 г.) / „Ондак смо дошли пред моју кућу. У дворишту стојао сточић, на њему сито са житом и кукурузом да га млада поспе по гостима и накоњче - дете из ближе фамилије, мало, јер га је одизала 3 пута.“(Соколовац, м. 70 г.). Дакле, у традиционалном моделу свадбених обичаја код Срба у селима Пољадије практикују се различити церемонијални обреди са истоветном магијско-религијском симболиком (култ плодности). Наведене разлике могу да се табеларно прикажу на следећи начин:

\begin{tabular}{|c|c|c|}
\hline \multicolumn{3}{|c|}{ долазак младе у нови дом } \\
\hline место & активност & предмети \\
\hline Луговет & „олакшавање“ порођаја & „живо “јаје \\
\hline Златица & $\begin{array}{c}\text { поздрављање кума и } \\
\text { старојка }\end{array}$ & хлеб \\
\hline Соколовац & $\begin{array}{c}\text { бацање жита и кукуруза / } \\
\text { одизање накоњчета }\end{array}$ & сито, жито и кукуруз \\
\hline
\end{tabular}

Табела бр.1: Локалне специфичности свадбених ритуала у три просторна контекста изражене у активностима и предметима који се користе приликом доласка младе у нови дом

\footnotetext{
${ }^{5}$ Проучавајући формално-структурне карактеристике прославе Божића, Весна ВучинићНешковић $[2008,23]$ наводи да су основни елементи прославе: време, простор, организатори, учесници, активности и предмети који се том приликом користе.
} 
Такође, казивања испитаника показују да у периоду од краја 1950-их година до почетка 1970-их година поједини основни елеменати прославе која прати склапање брака између супружника српске етничке заједнице постају сложенији: примера ради, за разлику од испитанице која је крајем 1950-их година склопила само грађански брак, јер „нико није тражио да се венчамо у Цркви“ (Луговет, ж. 77 г.), већ средином наредне деценије црквено венчање постаје обавезни део свадбених обичаја: „Ми смо се венчали 14. децембра 1966. године, већ је био почео Божићни пост, и шта ћемо одемо код попе, а он нам каже: „Где да се не венчате у Цркву, ја ћу вас венчати, па нас ваљда нико неће пријавити.“ (Златица, м. 69 г.); „намештаљка“, односно обичај да се током преузимања младе у њеном домаћинству изводи „лажна млада“ (,обично је то или нека баба или неки ситнији мушкарац или неко дете“ (Златица, м. 69 г.)) бележи се у обичајима на дан свадбе крајем 60-их година XX века, док игрокази, шаљиви скечеви и шале попут „крађе младе ${ }^{66}$, „воденице“7 и „мртваца“"8 постају саставни део свадбеног весеља почетком 1970-их година итд.

У контексту посматрања свадбе као идентитетског елемента Срба у селима Пољадије значајно је непоменути и то да је већина казивача (7 од 10 испитаника) у својим наративима акценат ставила на избор брачног партнеpa као основни поступак којим се изражава питање етничког идентитета српске мањине у посматраним селима:

„Ако си Србин онда узми Српкињу. Кад си Румун, узми Румунку. Ми смо биле четири сестре па смо све удате за Србине. Ја мојим синовима говорила: „Јој, немојте само Циганку да доведете!““ Циган када те погледа, из очију ти украде.“ (Луговет, ж. 75 г.).

„Гледало се то раније. Нису Српкиње баш тако лако ишле за Румуне. Да се не би мешале куће. И мом сину су се подсмевали јер му је отац био Румун.“ (Луговет, ж. 77 г.)

„Нико то није бранио. И у моју фамилију од Румуна се вучемо. Важно је да си поштен, па које год да си нације.“ (Луговет, м. 79 г.)

\footnotetext{
${ }^{6}$ „Е, онда се крала млада: узели је момци у кола и сакрили је негде. Па ја, наравно, морао да платим, па је после вратили, све шале ради!“ (Соколовац, м. 70 г.).

7 „И негде око 3 ујутру, кумић дремао, онај дремао, овај дремао и видео жарач да је дошло време за „воденицу“. То се спремило унапред и брашно и све, па смо као млели ту у сали, а то су сви гледали, сви су се пробудили. То је брашно требало да се плати, па опет тацна да се стављају паре. Ко није хтео да плати, жарач узме мало оног брашна и дуне на лепе аљине, па ти види хоћеш ли да платиш!“ (Соколовац, м. 70 г.).

8 „Ретко која свадба у Соколовац није имала „мртваца“. Када одмакне свадба, намешти се сандук од тишлера и ту се стављао неко ко је лак, а да је мало више попио. Припреми се кандило, запева се „Алелуја“ па пред кума: „Куме, овај није знао ни да једе ни да пије и види где је сада! Шта да радимо?“ Кум мора да плати парастос и да „мртваца“ изнесу из сале. Опет се та пара да музици или кицељашима, овима што служе!“ (Соколовац, м. 70 г.).
} 
„Није се бранило. И наши Румуни су као и Срби, па у исту се цркву овде крстимо. А са Циганима уопште не, они имају друго, своје...“ (Луговет, ж. 78 г.)

„Пре се то баш гледало. Иако смо живели јако добро као пријатељи, као комшије у село, али се нисмо мешали као брачни парови. Тако смо држали на веру. Сада су се Срби изгубили јако много због таквих бракова са Румуни, Чехи - Пемци, ми их тако зовемо, па чак и Роми са којима раније уопште није било бракова, ма какви. Иако су наши Цигани важили за поштене Цигане, радили код Срба, али где сам ја могао да дођем и кажем мом деди, оцу да волим Циганку, ма какви. Они су некако живели за себе. Данас деца не поштују старије, не поштују кућу, не поштују свеце. Почело са Румунима, па саде и са Циганима. И саде се губиду обичаји...“ (Златица, м. 69 г.)

„Пре су тражили свако своју веру да узмеду, али се касније све то измешало. Ето, мене је моја тетка удала за Румуна 1961. А од Рома се раније бегавало не питај. То је мој деда говорио: „Роми су људи само када их видиш из далека; када приђеш видиш да је Ром.“ А сада се Српкиње удају за Роме.“ (Златица, ж. 75 г.)

„Па раније се могло са Румунима, али са Циганима никако. Јер Циган је Циган, волели да украду. А сада и тога има и то много.“ (Златица, ж. 71 г.)

„Ми смо се Срби радовали да буде Српкиња. Саде узимају, право да ти кажем, и из циганске куће. Скоро се једна добра девојка, лепа девојка знаш како, ухватила са неким Циганом из Златице. И удала се за Цигана, правог Цигана. Ни оцу ни мајци није било свеједно. И одвео је Циган у Аустрију. Ма Циган - то је нешто најгоре што може да ти се деси.“ (Соколовац, м. 65 г.)

„Мој отац је гледао да то буде Србин, да не буде Румун. И једна и друга сестра и ја смо удате за Србе. Јер дешавало се да дође до неприлике па онда једни псују мајку српску, а други псују мајку румунску. Ипак нису Румуни као Срби.“ (Соколовац, ж. 92 г.)

„Није се то увек гледало, више се гледало да је кућа поштена, да су рађени (вредни, прим. аут.), да нису лопови, да девојка није бећаруша, да воли туђ мушки свет, како да кажем...“ (Соколовац, ж. 78 г.)

Испитаници су махом сагласни у томе да се међу српском мањином у посматраним румунским руралним заједницама, етничка ендогамија у већој мери практиковала све до 70-их година XX века. До наведеног периода у посматраним српским заједницама врло су ретки примери бракова са припадницима других етничких група (Румунима, Чесима, Ромима...). Избор брачног партнера (било да је одлуку доносила породица или будући младенци) био је условљен припадношћу истој (српској) етничкој заједници, односно ,друштвеној групи или категорији становништва која се, у великим заједницама, издваја и граничи помоћу заједничке расе, језика, националности или културе“. ${ }^{9}$ Имајући у виду специфичност друштвеног контекста

\footnotetext{
${ }_{9}^{9}$ Encyclopcedia Britannica, http://www.britannica.com/eb/topic-194248/ethnic-group
} 
у оквиру кога се свадбени обичаји посматрају, разумљива је реакција заједнице која настоји да у посебним условима сачува кохезију „спутавајући и осуђујући индивидуална права на рачун колективних“ [Златановић, 2003: 152]: „Где сам ја могао да дођем и кажем мом деди, оцу да волим Циганку, ма какви.“ (Златица, м. 69 г.) / „Мој отац је гледао да то буде Србин.“ (Соколовац, ж. 92 г.) / „Мом сину су се подсмевали јер му је отац био Румун.“ (Луговет, ж. 77 г.). ${ }^{10} \mathrm{C}$ обзиром на то да „склапање брака изазива велика померања у групи, јер су чланови заједнице међусобно повезани и промена позиције једног од њих у друштвеној структури захвата и све остале, због чега долази до нарушавања равнотеже“ [Златановић, 2003: 161], примарна функција формирања брачне заједнице између супружника исте (српске) етничке заједнице у посматраној вишенационалној и мултикултуралној средини била је „стабилизација етноса“ и спречавање процеса асимилације. ${ }^{11} \mathrm{Y}$ прилог наведеном говори и чињеница да су казивачи, по правилу, у својим наративима често користили именицу Србија и епитете изведене од наведене речи („То је била права српска свадба!““ (Луговет, ж. 77 г.); „Ја сам за своју свадбу све купио у Србији, од поклона до хране. И музика ми је била из Србије. Тако сам хтео, тако ми било драже.“ (Соколовац, м. 70 г.); „Ручак је био као код Србина.“ (Соколовац, ж. 92 г.); „Обичаји су били лепи, српски.“ (Златица, м. 69 г.); „Тако се славило и у Србији.“ (Златица, ж. 75 г.) итд.). Наведено јасно указује на то да свадбене ритуале као „веома разуђене и разрађене, дуго планиране и припремане приватне ритуале на јавној сцени“ [Златановић, 2007: 37], испитаници препознају као оперативне у процесу (само)идентификације у симбиози са Другима (Румунима, Чесима, Ромима...).

\section{3.}

\section{Уместо закључка}

Како наводе антрополошкиње Елинор Окс (Elinor Ochs) и Лиза Капс (Lisa Capps) свако причање наратива, смештено у времену и простору, ангажује само део нараторове или слушаочеве личности у смислу да евоцира само неке успомене, претпоставке и очекивања. У том смислу, наративи парцијално обухватају личност, односно тако обликовани наративи имају

\footnotetext{
${ }^{10}$ Због ограничености рада, процес „отворања“ српске етничке заједнице у погледу склапања мешовитих бракова услед друштвених промена насталих током друге половине XX века као и ритуали који прате склапање етнички хетерогених бракова биће предмет засебне анализе.

${ }^{11}$ Као облици асимилације јављају се: превођење имена лица и места са српског на румунски језик и непостојање двојезичних натписа; стално смањивање броја основних школа на језику српске мањине; смањивање броја културних и спортских друштава мањине; румунизација деце из мешовитих бракова и запошљавање стручњака из редова мањине у насељима где њихови припадници не живе [Cerović, 1997].
} 
приступ само фрагментима искуства [Sikimić, 2013: 24]. У случају приказаних личних прича припадника српске заједнице у селима Луговет, Златица и Соколовац, „наративи представљају парцијалне представе и евокације света какав наратори познају, па су, гледано из ове перспективе, наративи верзије стварности; они су оличење једне или више тачака гледишта пре него објективне, свезнајуће приче“ [Sikimić, 2013: 24]. С обзиром на то да су наративи интерактивна постигнућа, улога примарног примаоца је, у овом случају, да пружи повратну информацију о наративном доприносу, без амбиције да га „усклади, улепша, доведе у питање, изазива, оповргне или игнорише“ [Sikimić, 2013: 24]. Стварање целовите слике о најважнијем, најразрађенијем и садржински најбогатијем обичају животног циклуса српске мањине у посматраној мултикултуралној средини захтева поновни одлазак на терен и прикупљање додатних података.

\section{Литература}

Бандић, 2004: Д. Бандић, Народна религија Срба у 100 појмова. Београд: Нолит.

Вучинић-Нешковић, 2008: В. Вучинић-Нешковић, Божић у Боки Которској. Београд: Филозофски факултет Универзитета у Београду и Чигоја штампа.

Златановић, 2003: С. Златановић, Свадба-прича о идентитету. Београд: Етнографски институт САНУ.

Златановић, 2007: С. Златановић, Свадба и конструисање идентитета, у: Култура y трансформацији. Београд: Етнографски институт САНУ, 35-45.

Крстић, 2015: Б. Крстић, Народни живот и обичаји Клисураца и Пољадијаца. Темишвар: Савез Срба у Румунији.

Сикимић, 2013: B. Sikimić, Između dijalektologije i antropologije: bunjevačka terenska građa, u: Bunjevci. Etnodijalektološka istraživanja 2009. Novi Sad: Matica srpska i Bunjevački nacionalni savet, 13-69.

Степанов и Степанов, 2014: Љ. Степанов и В. Степанов, Статистички подащуи о Србима у Румунији. Темишвар: Савез Срба у Румунији.

Церовић, 1997: Lj. Cerović, Srbi u Rumuniji od ranog srednjeg veka do današnjeg vremena, http://www.rastko.rs/antropologija/ljcerovic_srbi_ro.html Преузето 19. 10. 2019. 
Bojana B. Bogdanović

\title{
MARKERS OF SERBIAN IDENTITY IN ROMANIA: WEDDING IN POLJADIJA
}

\begin{abstract}
Summary
During the field research in the villages of Lugovet, Zlatica and Sokolovac in July 2019, data about past and present ways of celebrating wedding among Serbs in Romania were collected. This traditional element was chosen because of the identity function he has not only for the Serbs in the country of origin, but also for the Serbs in diaspora, and thus consequently for the Serbs in Romania. Even today he (self)define ever decreasing Serbian national minority in the multicultural surroundings. This paper reviews the forms of celebration of wedding, considered in the ethnological/anthropological science as one of the key events in each individual's lifecycle, having a special significance considering the specificity of the social context in which it is observed.
\end{abstract}

Key words: customs, Poljadija, Romania, Serbs, wedding. 